\title{
TAX EXEMPTION OF STATE EMPLOYEES
}

\section{ROSWELL MAGILL}

Four recent decisions in the Federal courts, ${ }^{1}$ as well as an excellent article in this JOURNAL, ${ }^{2}$ have considered various aspects of the difficult question of the extent of the exemption of the salaries of state and municipal employees from the federal income tax. Many other articles ${ }^{3}$ have had as their texts the related question of the exemption of the interest on state and municipal bonds from the same tax. In view of this mass, of literature, an examination of the decisions and of their implications may well seem to be threshing old straw. But there has been no authoritative determination of the principal issue to be considered, and this decision, when made, will have many important incidental effects, which perhaps have not as yet been fully presented.

For the sake of clarity, this article will be confined to a consideration of the liability to federal income tax of the salaries or wages of officers or employees of states or municipalities. The related question of the liability of the state or municipality itself to federal tax upon income received by it from utilities will be discussed only in relation to the former problem.

\section{I}

The starting point for any discussion of a federal income tax question is, of course, the Sixteenth Amendment. It provides:

"The Congress shall have power to lay and collect taxes on incomes, from whatever source derived, without apportionment among the several States, and without regard to any census or: enumeration."

On the face of it, the amendment appears to give Congress the power to levy an income tax upon any sort of income regardless of its source. While the proposed amendment was being con-

1 Metcalf v. Mitchell (1926) 46 Sup. Ct. 172; Frey v. Woodworth (1924, E. D. Mich.) 2 Fed. (2d) 725 , dismissed in Supreme Court on motion of Solicitor General, (1926) 46 Sup. Ct. 347; City of Seattle v. Poe (1925, W. D. Wash.) 4 Fed. (2d) 276; Lyons v. Reineclee (1926, C. C. A. 7th) 10 Fed. (2d) 3.

2 Cohen and Dayton, Federal Taxation of State Activities and State Taxation of Federal Activities (1925) 34 YAle LAW Journal, 807.

3 Among others, see Corwin, Constitutional Tas Exemptions (1924) 13 Nat's MUNICIPAL Rev. 51; Anderson, The Problem of Tas-Exempt Sccurities (1924) 8 Minn. L. Rev. 273; T. R. Powell, The Sixteenth Amendment and Income from State Securities, The National Income Tax Magazine, July 1923.

4 Proclaimed by the Secretary of State to have been ratified by tho requisite number of states on February 25, 1913. 
sidered by the legislatures of the several states, there was much discussion as to whether it would give Congress the power to levy an income tax upon the interest upon state and municipal bonds, or upon the salaries of state officials." Various governors urged or opposed ratification upon the ground that such items of income might be taxed." The immediate cause of the amendment had been the decisions in the Pollock cases, ${ }^{7}$ that a tar upon certain kinds of income was unconstitutional in view of the sources of such income and of the failure to apportion the tax. Among the Iinds of income under consideration had been interest from municipal and state bonds. It was accordingly argued that the amendment was intended to put at rest any contention that the source of an item of income must be examined in determining whether it could be taxed. This construction of the amendment, though eminently plausible, has apparently been rejected by the Supreme Court in a series of well-known dicta, ${ }^{8}$ culminating in the decision of Evans $v$. Gore. ${ }^{9}$ Perhaps the most coraplete statement of the court's interpretation in this respect occurs in MIr. Chief Justice White's opinion in Stanton 2. Ealtic MLining Co.:20

"But aside from the obvious error of the proposition intrinsically considered, it manifestly disregards the fact that by the previous ruling it was settled that the provisions of the Sixteenth Amendment conferred no new power of taxation but simply prohibited the previous complete and plenary power of income tavation possessed by Congress from the beginning from being talien out of the category of indirect taration to which it inherently belonged and being placed in the category of direct taxation subject to apportionment by a consideration of the sources from which the income was derived, that is by testing the tax not by what it was -a tax on income, but by a mistaken theory deduced from the origin or source of the income taxed. Mark, of course, in saying this we are not here considering a tax not within the provisions of the Sixteenth Amendment, that is, one in which the regulation of apportionment or the rule of uniformity is wholly negligible because the tax is one entirely beyond the scope of the taxing

\footnotetext{
- See, for example, Foster, Income Tar (1914) 73 ct scq.; Minor, Tio Proposed Income Tav Amendment (1910) 15 VA. L. REs. 737, 753; Hubbard, The Sixieenth Amendment (1920) 33 H.Arv. L. FEv. 794; Graves, Inherent Improprieties in the Income Tas Amendmont to the Fcderal Constitution (1910) 19 YALE LAW JoURNAL, 505, 528.

${ }^{6}$ For a collection of such expressions, see Corwin, op. cit. supra note 3 ; Anderson, op. cit. supra note 3.

'Pollock v. Farmers' Loan \& Trust Co. (1895) 157 U. S. 420, 15 Sup. Ct. $673 ; 158$ U. S. 601,15 Sup. Ct. 912.

s See Brushaber v. Union Pacific R. R. Co. (1916) 2.10 U. S. 1 at 17, 1 S and 19, 36 Sup. Ct. 236 at 241 and 242; Stanton v. Ealtic Miz!ing Co. (1016) 240 U. S. 103, 112, 36 Sup. Ct. 278, 281; Eisirst 2'. MYcomber (1020) 252 U. S. 189, 204, 40 Sup. Ct. 189, 192; Pecle v. Loue (191S) $\mathbf{2 4 7}$ U. S. 165, 38 Sup. Ct. 432.

${ }^{9}$ (1920) 253 U. S. 245 , 40 Sup. Ct. 550.

20 Supra note 8 at 112,36 Sup. Ct. at 281.
} 
power of Congress and where consequently no authority to impose a burden either direct or indirect exists."

Likewise in Evans v. Gore, Mr. Justice Van Devanter, speaking for the majority, said :11

"True, Governor Hughes, of New York, in a message laying the Amendment before the legislature of that State for ratification or rejection, expressed some apprehension lest it might be construed as extending the taxing power to income not taxable before; but his message promptly brought forth from statesmen who participated in proposing the Amendment such convincing expositions of its purpose, as here stated, that the apprehension was effectively dispelled and ratification followed.

"Thus the genesis and words of the Amendment unite in showing that it does not extend the taxing power to new or excepted subjects, but merely removes all occasion otherwise existing for an apportionment among the States of taxes laid on income, whether derived from one source or another. And we have so held in other cases."

The soundness of the court's interpretation has been elaborately considered by other writers, ${ }^{12}$ some of whom have further upheld the thesis that the court has never actually decided whether. the interest on state and municipal securities or the salaries of state officials is subject to the federal income tax. ${ }^{13}$ It is reasonably clear, however, that whether its expressions are dicta or decisions, the court has come to the conclusion, thoughtfully considered, that if these items of income were not taxable by the federal government before 1913, they are not taxable after. Whatever exemption there is, however, rests not upon any express provision of the constitution, but upon constitutional implications. To determine its scope, then, it is necessary to review briefly the prior decisions of the Supreme Court defining the nature of the exemption.

\section{II}

The classic case upon the subject of the intergovernmental relations of the states and the nation for tax purposes is $\mathrm{McCulloch}$ $v$. Maryland. ${ }^{14}$ The general outline of Chief Justice Marshall's opinion therein is so well known to lawyers that it is only necessary to focus attention upon a few features of it which are peculiarly pertinent to this discussion. In the first place, the $\operatorname{tax}$ involved was a state stamp tax upon the note issue of the Bank of the United States; the tax applied to note issues of banks operating in the state and not chartered by the legislature. In other words, the tax was obviously discriminatory; it was evi-

11 Supra note 9 at 261, 40 Sup. Ct. at 556.

12 See, for example, Rottschaefer, Federal Taxation of "Exempt" Income (1924) 8 MrNN. L. Rev. 112; Corwin, op. cit. supra note 3.

13 See particularly Professor Corwin's article supra note 3.

14 (1819) 4 Wheat. 316. 
dently the particular manifestation by the Mraryland legislature of a desire prevailing in the several states to drive the Bank out of business. ${ }^{25}$ In the second place, it is evident that, on these facts, the decision involved only the state power to tax and not the federal power. The famous expression "That the power to tax involves the power to destroy" 1 sas not used in respect of the porrers of the federal government. Indeed MIr. Chief Justice Miarshall expressly indicated that there need be no such fear of a destructive exercise of its taxing powers by the national government.17 It cannot fairly be said, then, that MIr. Chief Justice iIarshall held that "to safeguard our constitutional system, therefore, the right of taxation by the one sovereignty upon any power of the other must be wholly denied." 19

The leading case upon the power of Congress to levy an income

${ }^{15}$ See 4 Eeveridge, The Life of Joha Marshall (1919) ch. VI; 1 Warren, The Supreme Court in United States History (1922) 504 et seq.

10 "But, waiving this theory for the present, let us resume the inquiry" whether this power can be exercised by the respective States, consistently with a fair construction of the constitution?

"That the power to tax involves the power to destroy; that the power to destroy may defeat and render useless the power to create; that there is a plain repugnance, in conferring on one government a power to control the constitutional measures of another, which other, with respect to those very measures, is declared to be supreme over that which eserts the control, are propositions not to be denied. . . ." McCulloch ". Maryland, aupha note 14 at 430 .

17 "It has also been insisted, that, as the power of taxation in the general and State governments is acknowledged to be concurrent, every argument which would sustain the right of the general government to tax banlso chartered by the States, will equally sustain the rights of the States to tax banks chartered by the general government.

"But the two cases are not on the same reason. The people of all the States have created the general government, and have conferred upon it the general power of taxation. The people of all the States, and the States themselves, are represented in Congress, and, by their representatives, exercise this power. When they tax the chartered institutions of the States, they tax their constituents; and these tases must be uniform. But, when a State taxes the operations of the government of the United States, it acts upon institutions created, not by their own constituents, but by people over whom they claim no control. It acts upon the measures of a government created by others as vell as themselves, for the benefit of others in common with themselves. The difference is that which always exists, and always must exist, between the action of the whole on a part, and the action of a part on the whole-between the laws of a government declared to be supreme, and those of a government which, when in opposition to those laws, is not supreme." McCulloch v. Maryland, auzras - note 14 at 435 .

Is Cohen and Dayton, op. cit. supra note 2 at $812-3$. C $C$. the statement at 807-8: "Ever since the decision in MrCulloch v. Marjland it has been laid down as a general rule that each government, and by that term was comprehended the political subdivisions of each as well, was free from any burden of taxation attempted to be imposed by the other." 
tax upon the salaries of state officials is Collector v. Day, which involved the question whether the salary of a state judge was subject to tax under the Civil War income tax acts. Mr. Justice Nelson said in part: $:^{20}$

"It is admitted that there is no express provision in the Constitution that prohibits the general government from taxing the means and instrumentalities of the States, nor is there any prohibiting the States from taxing the means and instrumentalities of that government. In both cases the exemption rests upon necessary implications, and is upheld by the great law of self-preservation; as any government, whose means employed in conducting its operations, if subject to the control of another and distinct government, can exist only at the mercy of that government."

“**** the means and instrumentalities employed for carrying on the operations of their governments, for preserving their existence, and fulfilling the high and responsible duties assigned to them in the Constitution, should be left free and unimpaired, should not be liable to be crippled, much less defeated by the taxing power of another government."

If it be regarded as settled, then, that the Sixteenth Amendment did not extend the taxing powers of Congress to sources of income previously exempt, it appears that the "means and instrumentalities employed for carrying on the operations of their [the states'] governments, for preserving their existence, and fulfilling the high and responsible duties assigned to them in the Constitution" are not subject to the federal income tax. The next question is whether all enterprises in which a state or a municipality may engage are embraced within the phrase, and whether all individuals receiving income from such enterprises are exempt in respect of it from federal taxation.

The most recent authoritative judicial expression is that of Mr. Justice Stone in Metcalf $v$. Mitchell.21 The question considered was the liability to income tax of amounts received by consulting engineers as compensation for their services under contracts with various states, municipalities, or water or sewage districts created by state statute. The court held such compensation taxable. The reasoning is that the extent of the exemption claimed depends upon (1) the effect of the tax upon the government alleged to be burdened, ${ }^{22}$ and (2) the nature of the

19 (1871) 11 Wall. 113.

20 Collector v. Day, supra note 19 at 127 and 125.

21 Supra note 1.

22 Metcalf $v$. Mitchell, supra note 1 at 174: "As cases arise, lying between the two extremes, it becomes necessary to draw the line which separates those activities having some relation to government, which aro nevertheless subject to taxation, from those which are immune. Experience has shown that there is no formula by which that line may be plotted with precision in advance. But recourse may be had to the reason upon which the rule rests, and which must be the guiding principle to control its operation. Its origir, was due to the essential requirement of our con- 
governmental agencies. 23 It is a clear inference from the opinion, if not its expression, that various enterprises of the state may be subject to federal taxation; the court cites for this proposition with approval the South Carolina liquor case ${ }^{2 a}$ and Flint $v$. Stone-Tracy Co., ${ }^{25}$ which will be discussed below. The further strong inference is that a non-discriminatory income tax upon individuals receiving compensation from the state, who are not officers or employees of government, may not be deemed an interference in any substantial way with the state government. This aspect of the case will be further considered under III below. Since the engineers in the particular case held no oficial positions, were free to accept other employment, and did not show that their duties were defined or prescribed by statute, the court concluded that they were not officers or employees of the states

stitutional system that the federal government must exercise its authority within the territorial limits of the states; and it rests on the conviction that each government, in order that it may administer its afrairs within its own sphere, must be left free from undue interference by the other. IIcCulloch v. Mfaryland, supra; Collector v. Day, supra; Commissioncrs of Erie County, supra. . . .

"While it is evident that in one aspect the extent of the cxemption must finally depend upon the effect of the tax upon the functions of the government alleged to be afiected by it, still the nature of the governmental agencies or the mode of their constitution may not be disregarded in passing on the question of tax exemption; for it is obvious that an agency may be of such a character or so intimately connected with the exereice of a power or the performance of a duty by the one government, that ang taxstion of it by the other would be such a direet interference with the functions of government itself as to be plainly beyond the taxing power."

23 Metcalf v. Mitchell, supra note 1 at 175: "It is on the principle that, as we have seen, any taxation of one govemment of the salary of an offeer of the other, or the public securities of the other, or an agcney created and controlled by the other, exclusively to enable it to periorm a gorernmental function (Gillespie v. Ollahoma, supra), is prohibited. But here the tax: is imposed on the income of one who is neither an oficer nor an criployes of government and whose only relation to it is that of contract, under which there is an obligation to furnish service, for practical purpores not unlike a contract to sell and deliver a commodity. The tax is impoced without discrimination upon income whether derived from services rendered to the state or services rendered to private individuals. In such a situntion it cannot be said that the tax is imposed upon an agency of government in any technical sense, and the tax itself cannot be deemed to be an interference with government, or an impairment of the efleiericy of its agencies in any substantial way. Railroad Co. v. Peniston; Gromer v. Standard Dredging Co.; Baltimore Shipbuilding Co. v. Baltimore; Fidelity \& Deposit Co. v. Pennsylvania; Choctaw, O. \& G. R. R. Co. v. Macliey, supra."

24 South Carolina v. Uszited States (1905) 190 U. S. 437, 26 Sup. Ct. 110. 25 (1910) 220 U. S. 107, 31 Sup. Ct. 342.

26 The Treasury had held that "in order to be an officer or employee it must appear that the duties performed by such person are of a continuous nature and are not occasional, temporary, or specific in character or object." 
within the meaning of the statutory exemption; $;$ that there was no constitutional prohibition against taxing them.

It appears, then, that the Supreme Court has concluded that officers and employees of states and municipalities are exempt from the federal income tax $;^{28}$ but that not all who receive compensation from the state or city are within the exemption. In the taxable category are, according to the Metcalf case, individuals who hold no regular official position in the state or municipality. That case further calls attention to the non-exempt state enterprises defined in the South Carolina liquor case and in Flint $v$. Stone-Tracy Co. To complete this study of the scope of the federal power to tax incomes derived from states or municipalities, it is necessary to examine these earlier decisions.

In South Carolina $v$. United States ${ }^{20}$ the court passed upon the power of the United States to collect license taxes from dealers selling liquor in dispensaries established by the state, whose profits belonged to the state. The court, in upholding the tax, said in part: $: 30$

"There is something of a conflict between the full power of the Nation in respect to taxation and the exemption of the State from Federal taxation in respect to its property and a discharge of all its functions. $* *$ The exemption of the State's property and its functions from Federal taxation is implied from the dual character of our Federal system and the necessity of preserving the State in all its efficiency. In order to determine to what extent that implication will go we must turn to the condition of things at the time the Constitution was framed. * * Looking, therefore, at the Constitution in the light of the conditions surrounding at the time of its adoption, it is obvious that the framers in granting full power over license taxes to the National Government meant that that power should be complete, and never thought that the States by extending their functions could practically destroy it.

"It is also worthy of remark that the cases in which the invalidity of a Federal tax has been affirmed were those in which the tax was attempted to be levied upon property belonging to the State, or one of its municipalities, or was a charge upon the means and instrumentalities employed by the State, in the discharge of its ordinary functions as a government.

"These decisions, while not controlling the question before us, indicate that the thought has been that the exemption of State agencies and instrumentalities from national taxation is limited to those' which are of a strictly governmental character, and does

(1921) Sol. Op. 122, 5 Int. Rev. Cum Bull. 108. This test is severoly criticized in a note in (1925) 38 HARV. L. REV. 793 at 797.

27 Contained in sec. 201 (a) of the Revenue Act of Oct. 3, 1917 (40 Stat. at $L$. 303), but not repeated in succeeding acts.

28 To the same effect is (1919) 31 Op. Atty. Gen. 441, and Art. 88 of U. S. Treas. Reg. 62 and 65 .

29 Supra note 24.

30 Supra note 24 at 456,26 Sup. Ct. at 114. 
not extend to those which are used by the State in the carrying on of an ordinary private business. [Italics mine.]

"It is reasonable to hold that while the former may do nothing by taxation in any form to prevent the full discharge by the latter of its governmental functions, yet whenever a State engages in a business which is of a private nature that business is not withdrawn from the taxing power of the Nation."

There are similar expressions in Salt Lake City v. Hollister,; where a city engaged in distilling spirits was held to be subject to internal revenue taxation under the laws of the United States.

In Flint $v$. Stone-Tracy Co.32 the court considered the application of the corporation excise tax act of 1909 to so-called publicservice companies. The court said, in part: ${ }^{33}$

"It is no part of the essential governmental functions of a State to provide means of transportation, supply artificial light, water, and the like. These objects are often accomplished through the medium of private corporations, and, though the public may derive a benefit from such operations, the companies carrying on such enterprises are, nevertheless, private companies, whose business is prosecuted for private emolument and advantage. For the purpose of taxation they stand upon the same footing as other private corporations upon which special franchises have been conferred.

"The true distinction is between the attempted taxation of those operations of the States essential to the execution of its governmental functions, and which the State can only do itself, and those activities which are of a private character. The former, the United States may not interfere with by taxing the agencies of the State in carrying out its purposes; the latter, although regulated by the state, and exercising delegated authority, such as the right of eminent domain, are not removed from the field of legitimate Federal taxation."

These decisions are uniform, then, in dividing the activities of a city or state into two classes for purposes of federal taxationproprietary and governmental; the first group is a proper object of federal taxation, ${ }^{3 s}$ the latter is not. It is hardly a matter of

sI (1886) 118 U. S. 256, 6 Sup. Ct. 1055.

32 Supra note 25.

33 Supra note 25 at 172,31 Sup. Ct. at 357.

34 The Treasury has so ruled with respect to the income tax upon the compensation of individuals working for a municipal street railway in (1923) Sol. Op. 152, Int. Rev. Cum. Bull., II-2, p. 93. Miessrs. Cohen and Dayton suggest, op. cit. supra note 2 at 809,810 , that the test laid down in this opinion is "the distinction which has grown up in determining the tort liability of the public bodies to individuals." A careful reading of the opinion indicates, however, that it is based on the distinction for federal tax purposes between various activities of the state and municipalities as drawn in South Carolina v. United States, supra note 24; Banlo of United States v. Planters' Bank (1824) 9 Wheat. 904; Salt Lalic City v. Hollister, supra note 31; Flint v. Stone-Tracy Co., supre note 25; and Vilas $v$. Manila (1911) 220 U. S. 345, 31 Sup. Ct. 416. The tort distinction is referred to, but does not appear to be made controlling. 
present importance that Mr. Justice White dissented in the South Carolina case; that case has never been overruled, and is expressly approved by the unanimous court in Flint v. Stone-Tracy Co. and in the recent Metcalf case. For similar reasons, the South Carolina case cannot be disposed of as standing alone, and resting upon a peculiar state of facts, ${ }^{35}$ for the Supreme Court has applied the same distinction in at least four succeeding cases. Moreover, it is hardly convincing to argue that the distinction in the tort field between governmental and proprietary activities is elusive and illogical; that consequently any such distinction in the field of taxation is likewise illogical. ${ }^{37}$ The tort distinction apparently is founded on special grounds not at all applicable to taxation, probably particularly on the ground of the peculiar hardship to an individual negligently injured to have no redress against a responsible defendant. It may well be, as has been urged, ${ }^{38}$ that one negligently injured by a government employee or officer should uniformly be given the power to sue the government. But how does this conclusion bear upon the income tax liability of the government employee? The Supreme Court does not rely upon the tort cases as establishing any distinction in the field of taxation; they are referred to in the South Carolino case, but the decision rests upon the much broader grounds already referred to- that a state by engaging in a private business, does not thereby remove that business from the field of non-discriminatory federal taxes imposed upon all such businesses.

\section{III}

Although there is an abundance of authority for distinguishing for federal tax purposes between the proprietary activities of the state and its governmental functions, there are no decisions by the Supreme Court specifically applying this distinction to the income tax upon the compensation of its officers and employees. Should the court hold, then, that although a state judge is not taxable upon his salary, a motorman, employed by a municipally owned street railway, is?

The decisions already referred to certainly appear to point to that conclusion. If, as was said in Flint v. Stone-Tracy Co., "it is no part of the essential governmental functions of a State to provide means of transportation, supply artificial light, water and the like," ${ }^{39}$ the reason given for the exemption of the salary

35 Cohen and Dayton, op. cit. supra note 2 at 820.

${ }^{30}$ Salt Lake City v. Hollister, supra note 31 ; Vilas v. Manila, supra note 34; Flint v. Stone-Tracy Co., supra note 25; Metcalf v. Mitchell, supra note 1.

${ }^{37}$ See Cohen and Dayton, op. cit. supra note'2 at 810.

38 See Borchard, Government Liability in Tort (1924-5) 34 YALE LAw: JOURNAL 1, 129, 229.

39 Supra note 25 at 172,31 Sup. Ct. at 357. 
of the state judge in Collector $v$. Day ${ }^{30}$ does not apply to the case of the motorman. For, on this premise, "the means and instrumentalities employed for carrying on the operations of their governments" are not being affected by the tax. Or if, as was held in the South Carolina, ${ }^{11}$ case, a federal license tax may properly be imposed upon state-employed dispensers of intoxicating liquors, the tax being in fact paid by the state, there can hardly be any constitutional objection to the imposition of the federal income tax upon the salary received by the dispenser, the tar being in fact paid out of his own pocket. Or, to use the language of Metcalf $v$. Mitchell, a federal income tax, which "is imposed with. out discrimination upon income whether derived from services rendered to the state, or services rendered to private individuals" may be collected from "one who is neither an officer nor an employee of government," since "in such a situation it cannot be said that the tax is imposed upon an agency of government in any technical sense, and the tax itself cannot be deened to be an interference with government, or an impairment of the efrieiency of its agencies in any substantial way."

At this point, it should perhaps be emphasized that it is confused analysis to consider the federal tax upon income aceruing to the state from a state enterprise as being analogous to the federal tax upon income accruing to an individual emplovee, or that the two taxes stand or fall by virtue of the same arguments. Since United States $v$. Baltimoie \& Ohio $R$. R. Co., is it may be questioned whether the state's income can be tased; at any rate, Congress has been sedulous in exempting it." Such a tax would be a very obvious and direct drain upon the state revenues in favor of the federal government. But the tax upon the compensation of an employee of some proprietary enterprise of the state in no sense falls upon the state. The state is in no way handicapped in bargaining for employees against private employers. In many cases of state-owned businesses, the business was acquired from private ownership. The employee's compensation remains the same, if the tax is imposed upon his salary, that it was before. If an exemption is granted, his compensation is in substance increased to that extent. To that extent, the state

\footnotetext{
40 Supra note 19.

41 Supra note 24.

12 Supra note 1 at 175.

43 (1873) 17 Wall. 322.

13 See Act of Oct. 3, 1913, Sec. IIG (a) (3S Stat. at L. 172); Act of Sept. 8, 1916, Sec. 11(b) (39 Stat. at L. 767); and Rev. Acts of 1918, 1921, 1021 and 1926, Sees. $213(b)(7)$.

The wording of the first paragraph of the exemption provision in all the acts-"Income derived from any public utility or (from) the exercice of any essential governmental function . . " etc-itself indicates that Congress had in mind the distinction here insisted upon, that betwcen essential governmental activities, and proprietary activities.
} 
employee is being favored over the private employee performing the same service.

Since the decision of the question will evidently turn upon the actual effect upon the state of the grant or the refusal of the exemption, it is not irrelevant to consider the difference in setting between the day of McCulloch v. Maryland and today. At that time, the phrase "the power to tax involves the power to destroy" had a very real meaning - the states were actively engaged in attempting to destroy the United States Bank, as well as to weaken the authority of the federal government. In the face of the increasing co-operation, between the federal and state governments at the present time, it could hardly be contended that either is attempting or would attempt to destroy the other by discriminatory taxation. Again, the levy of the federal income tax upon the wages of an employee of a state-owned business enterprise is not, as has been urged, an attempt by the federal government to discourage state experiments in business. ${ }^{45}$ It is conceived that such a levy is justified, not only that the state enterprise may be given no unfair advantage in competition with private enterprise of the same sort, but also that the mass of income taxpayers of the United States, not employed by states or cities, may not be called upon to make up by a corresponding increase in their taxes, the amount of taxes which otherwise would be collectible from the state employees, and to that extent to subsidize the business venture of the state. It can scarcely be urged, as a practical proposition, that the prospective or actual levy of a federal income tax on the wages of a motorman of the Detroit Street Railway will have any possible discouraging effect upon the city's undertaking such an enterprise. On the other hand, why should a motorman of the Detroit Street Railway be exempted from a tax which the motorman of the privately owned Chicago Street Railway is compelled to pay?

Students of federal revenue legislation have noticed, as a recurring phenomenon, the increase in the exemptions granted by the acts. The evils of exemptions are reasonably obvious. In the first place, the exemption of any particular class of taxpayers or of income necessarily requires that the remaining classes of taxpayers and of income bear a burden heavier by so much.

45 Messrs. Cohen and Dayton, op. cit. supra note 1 at 832 apparently concede this as their final conclusion: "Neither does it seem that tho question of municipal ownership or control of public utilities is as closoly bound up with this question of tax exemption as is generally assumed." The opening paragraphs of their discussion sound a somewhat different note: "Yet implicit in the problem of that case Frey v. Woodworth, supra note 1 are questions the final answer to which may well change the whole course of our municipal development and activities, and may even be a vital factor in the discard or retention of the political philosophy upon which our government was founded and by which until recent years it has largely been guided." 
Again, the administration of the law is considerably complicated by the necessity of ruling upon the qualifications of a steadily increasing number of applicants for the different sorts of exemptions. No doubt either of these objections is outweighed by the meritorious claims of such well-known exemptions as educational institutions or charities. But for the reasons shown, the claims of the particular group of taxpayers here involved for special privileges do not seem particularly strong.

For these reasons, it is to be regretted that Congress inserted into the Revenue Act of 1926 the provision: ${ }^{46}$

"Any taxes imposed by the Revenue Act of 1924 or prior revenue acts upon any individual in respect of amounts received by him' as compensation for personal services as an officer or employee of any State or political subdivision thereof (except to the extent that such compensation is paid by the United States Government directly or indirectly), shall, subject to the statutory period of limitations properly applicable thereto, be abated, credited, or refunded."

With the Supreme Court about to decide the constitutional question involved, with the Treasury committed to the collection of the tax and having collected it, there seems to be no sound reason why these taxpayers should be the recipients of a special refund, to which, so far as one can determine from earlier decisions, they are not entitled. MIoreover, it will be observed that this language does not make it clear that an officer or employee of a state-owned private enterprise is exempt from federal income tax, either in 1924 and preceding years, or today. The Treasury has previously ruled that such individuals are not officers $0 \mathrm{r}^{\circ}$ employees of the State for the purposes of this exemption.: If the Treasury's previous view were adopted, the question in Ficl $v$. Woodworth $h^{4 s}$ - whether the compensation of an employee of the Detroit Street Railway for 1923 is subject to the federal income tax-would still be unsettled. ${ }^{43}$ So far as taxation under the 1926 act is concerned, the question seerns to remain wholly open. In other words, Congress gave no assistance in the solution of the problem here considered; it merely added the new hurdle of an ambiguously drawn statutory provision to the other obstacles in the course. But perhaps it is fortunate that the exemption is no clearer. All the reasons cited against a judicially determined exemption apply with equal force against a legislative exemption.

\footnotetext{
40 Sec. 1211.

47 Supra note 34.

48 Supra note 1.

49 The case was, however, dismissed on motion of the Solicitor General, (1926) 46 Sup. Ct. 347, following the passage of the 1926 Act, evidently on the theory that the particular employee of the street railway was an employee of the municipality within the meaning of section 1211.
} 
The final question is, assuming that persons employed in the proprietary activities of the State are taxable by the federal government upon their incomes, where is the line to be drawn separating the proprietary from the governmental activities. No doubt it will be difficult to draw any line at all in many cases; but that difficulty is hardly an argument against making the distinction. As Mr. Justice Holmes has said: $:^{50}$

"Neither are we troubled by the question where to draw the line. That is the question in pretty much everything worth arguing in the law."

There are at least two possibilities. Following Mr. Justice Nelson's language, ${ }^{51}$ the governmental activities of the State may be considered to be merely the historically essential governmental activities. It seems to be a well recognized rule that exemptions should be strictly construed. On such a basis, the salaries of officers or employees of a municipally-owned water system,,$^{62}$ or of a port district, ${ }^{53}$ of a state employment agency, or of a state-

so Irvin v. Gavit (1925) 268 U. S. 161, 168, 45 Sup. Ct. 475,476 . See also his similar language in his dissent in Schlesinger $v$. State of Wisconsin (1926) 46 Sup. Ct. 260, 262.

${ }^{61}$ Quoted supra, p. 960.

62 See (1924) Sol. Mem. Op. 2232, Int. Rev. Cum. Bull. III-2, p. 83.

Frey v. Woodworth, supra note 1, involved the question whether the compensation of officers and employees of the municipally-owned Detroit Street Railway was subject to the federal income tax. The district court, although fully recognizing the distinction between the governmental and proprietary activities of the state, held that these salaries were not taxable, evidently on the ground that the operation of a street railway was a governmental function. The court relied on United States v. King County, Wash. (1922, C. C. A. 9th) 281 Fed. 686, holding that a county operating a ferry need not collect and pay over the federal transportation tax. Asido from the difference in the incidence and methods of collection of the two taxes, the cases seem readily distinguishable on the ground that while the maintenance of highways, bridges, or even ferries may be a proper governmental function, the maintenance for profit of a street railway upon such highways is surely not an essential governmental function, within Collector v. Day. In. City of Seattle v. Poe (1925, W. D. Wash.) 4 Fed. (2d) 276 , arising in the circuit in which U.S. v. King Co. was decided, the court distinguished the operation of a ferry from the operation of a street railway on this basis, and held that the collection of the federal income tax from the employees of the Seattle municipal street railway would not be enjoined. See also discussions of Frey $v$. Woodworth, disapproving its conclusions in (1925) 25 CoL. L. REv. 653, note, and (1925) 38 HARv. L. REv. 793.

See also Lyons $v$. Reinecke, supra note 1 , holding that the federal income tax exacted for 1920 on compensation received for expert real estate appraisal services rendered to the Chicago Board of Local Improvements and paid out of the proceeds of city bonds could not be recovered by the taxpayer.

${ }^{53}$ Supra note 52. 
operated gasolene station would be subject to the tax. It would be easier to define this category than any other suggested, and if the premise is accepted that the exemptions of the salaries of state officials, being unfortunate in any case, should be restricted as far as possible, a conclusion in favor of this division follows. On the other hand, courts may be persuaded to add in effect to the customary two categories of governmental and proprietary activities a third classification of businesses affected with a public interest, and to hold that the compensation of the officers or employees of one of these businesses, if state-operated, is exempt from federal tax.5. In view of the prospective or actual ventures of states and cities into the ownership and operation of street railways, water-works, gas plants, housing projects, workmen's compensation insurance funds, grain elevators and so on, this latter conclusion will sooner or later noticeably affect the national revenues from the income tax, and may even lead to a demand for the abolition of the tax, on the ground of the inequalities in its incidence. In any event, the decisions as to the scope of this implied exemption, originating in Collector $v$. Day, and unfortunately not set at rest by the Sixteenth Amendment, will be among the most important in this field of law.

\footnotetext{
54 Messrs. Cohen and Dayton apparently advocate some such distinction as this; they urge that the exercise or the grant of the porver of eminent domain furnishes an analogy for the grant of an exemption from tasation. See op. cit. supra note 2 at 822-5. Cf., however, the quotation from Fliat v. Stone-Tracy Go., supra, p. 963.
} 